\title{
Digital Marketing Strategies and International Patients' Satisfaction: An Empirical Study in Jordanian Health Service Industry
}

\author{
GHAZI A. AL-WESHAH ${ }^{1}$, DANA F. KAKEESH ${ }^{2}$; NOOR A. AL-MA'AITAH ${ }^{3}$ \\ ${ }^{1}$ Department of Marketing, Faculty of Business, AL-BALQA APPLIED UNIVERSITY, JORDAN \\ E-mail: ghazi.alweshah@bau.edu.jo \\ ${ }^{2}$ Department of Marketing, School of Business, THE UNIVERSITY OF JORDAN, JORDAN \\ E-mail: dana.kakeesh@ju.edu.jo \\ ${ }^{3}$ Department of Business Administration, School of Business, MUTAH UNIVERSITY, JORDAN \\ E-mail: nmaaitah@mutah.edu.jo
}

\begin{abstract}
The study aims at investigating the role of digital marketing strategies in enhancing international patients' satisfaction in Jordanian healthcare industry. Specifically, the effect of search engine optimization, social media networks, and e-mail marketing as digital marketing strategies on international patients' satisfaction. The quantitative approach is adopted and 400 questionnaires are distributed using convenient sample to international patients in different health service organizations (HSO). Only 310 questionnaires were collected with response rate $78 \%$. The study concluded that there is a significant effect of digital marketing strategies on international patients' satisfaction in Jordanian health service industry. Moreover, each digital marketing strategies (search engine optimization, social media networks, and e-mail marketing) have a significant effect on international patients' satisfaction in Jordanian health service industry. Moreover, social media networks are the most important strategy which are employed to enhance patients' satisfaction in HSOs. The study recommends that HSOs have to take the advantages of digital marketing strategies in order to enhance patients' satisfaction. Practical implications and directions for future research are proposed.
\end{abstract}

Keywords: Digital marketing; Patients' satisfaction; Health service industry; Search engine optimization; Social media networks; E-mail marketing.

JEL Classification: C1, L2 


\title{
Estrategias de Marketing Digital y Satisfacción de los Pacientes Internacionales: Un Estudio Empírico en la Industria Jordana de Servicios Sanitarios
}

\author{
GHAZI A. AL-WESHAH ${ }^{1}$, DANA F. KAKEESH ${ }^{2}$; NOOR A. AL-MA'AITAH ${ }^{3}$ \\ ${ }^{1}$ Department of Marketing, Faculty of Business, AL-BALQA APPLIED UNIVERSITY, JORDAN \\ E-mail: ghazi.alweshah@bau.edu.jo \\ ${ }^{2}$ Department of Marketing, School of Business, THE UNIVERSITY OF JORDAN, JORDAN \\ E-mail: dana.kakeesh@ju.edu.jo \\ ${ }^{3}$ Department of Business Administration, School of Business, MUTAH UNIVERSITY, JORDAN \\ E-mail: nmaaitah@mutah.edu.jo
}

\begin{abstract}
RESUMEN
El estudio pretende investigar el papel de las estrategias de marketing digital en la mejora de la satisfacción de los pacientes internacionales en el sector sanitario jordano. En concreto, el efecto de la optimización de los motores de búsqueda, las redes sociales y el marketing por correo electrónico como estrategias de marketing digital en la satisfacción de los pacientes internacionales. Se adopta el enfoque cuantitativo y se distribuyen 400 cuestionarios mediante una muestra conveniente a pacientes internacionales en diferentes organizaciones de servicios sanitarios (HSO). Sólo se recogieron 310 cuestionarios con una tasa de respuesta del 78\%. El estudio concluye que existe un efecto significativo de las estrategias de marketing digital sobre la satisfacción de los pacientes internacionales en el sector de los servicios sanitarios jordanos. Además, cada una de las estrategias de marketing digital (optimización de motores de búsqueda, redes sociales y marketing por correo electrónico) tiene un efecto significativo en la satisfacción de los pacientes internacionales en el sector sanitario jordano. Además, las redes sociales son la estrategia más importante que se emplea para mejorar la satisfacción de los pacientes en los centros de salud. El estudio recomienda que las HSO aprovechen las ventajas de las estrategias de marketing digital para mejorar la satisfacción de los pacientes. Se proponen implicaciones prácticas y direcciones para futuras investigaciones.
\end{abstract}

Palabras clave: Marketing digital; Satisfacción de los pacientes; Industria de servicios sanitarios; Optimización de motores de búsqueda; Redes sociales; Marketing por correo electrónico.

Clasificación JEL: C1, L2 


\section{Introduction}

Jordan has one of the most modern health care infrastructures in the Middle East and marked several achievements in the medical and healthcare sector (Alsarayeh et al, 2017; Al-Weshah, 2019a). In 2019, the number of international patients looking for health services in Jordan reached 220,000 patients. Furthermore, the health service sector contributed USD 1.2 billion to Jordan's GDP in 2015. Further statistics showed that 197,385 people from various nationalities, as well as 22,700 Libyan, 31,163 Yemenis, 130,911 Iraqis, 634,182 Palestinians and 636,370 Egyptians resided in Jordan in 2015, according to the Department of Statistics (DoS). Of these individuals who access health service industry there were two groups, the first group is who travel aboard intentionally for health care service and medical treatment while the second group is patients who are already aboard and who become sick during their stay and need a healthcare. These two groups are temporary or migrant patients ${ }^{1}$.

As Dhodi (2014) has related, the HSO is seeing increased global competition due to the sector being increasingly appealing to various countries internationally. Medical Tourism Magazine (2010) explained that local economic development has been fundamentally perpetuated through HSOs in India, Singapore, Jordan and other states. Al-Sarayerh et al. (2017) provided one instance of this, where in 2016 over USD 1.2 billion in income was made in Jordan from medical tourism.

Due to technological advancement in recent years, the practices of HSOs have also changed dramatically. The governments have to move faster in order to gain the competitive advantages and follow the trend in medical sector and be ahead in the regional competition as well as the global one (Dhodi et al. 2014). Accordingly, Al-hinai et al. (2011) observed how legislation pertaining to medical standards, for example the Joint Commission International Accreditation (JCIA) for health care instaurations, has been introduced by numerous countries like Jordan, Singapore, and India. Furthermore, patients' satisfaction is receiving greater attention as a means of determining the gap in health care service delivery process, hence, HSOs' can enhance the standards, as well as to integrated approaches to overcome shortcomings (Abriand Al-Balushi, 2014). Moreover, public and private HSOs in Jordan have combined their efforts to support the healthcare sector through promoting Jordan's medical tourism sector (Al-Azzam, 2016;Al-Sarayerh et al. (2017)

\section{The study gap}

In order to strengthen strategic plans and healthcare service quality, HSOs are obliged to consider their patients' satisfaction (Al-Rabi and Al-Balushi, 2014). As Vogus and McClelland (2016) claimed that the patients consider themselves as buyers of healthcare services and since patients have been given an opportunity to choose among different HSOs in a country, and sometimes among different HSOs overseas. Therefore, Tartaglione et al. (2018) noted that the particular patients' needs and wants must be acknowledged. In addition, a number of studies recognized that higher patient satisfaction has an impact on HSOs in different terms such as increase patients' loyalty, improved patients' retention, will yield more profit, less staff turnover, and more staff satisfaction. Adding to that in many countries it is one of accreditation requirement (Burkle et al., 2017; Al-Weshah, 2017; Tartaglione et al. 2018)

In terms of attaining high health service standards, a vital requirements and standards have to be maintained to achieve high level of patients' satisfaction. Many studies have demonstrated that medical facilities' savings, revenue and market share are directly affected by high service standards (Chiou and Droge, 2006; Becerril-Arreola et al., 2017; Burkle et al., 2017; Tartaglione et al., 2018. Kumar and Hussian, 2016). Kuala Lumpur's healthcare sector was assessed by Kumar and Hussain (2016) in terms of variables enticing medical tourism, with patients' satisfaction found to be beneficially and directly influenced by Malaysia's geography and other country-specific conditions, as well as institutional efficacy in Kuala Lumpur, among various other factors influencing health tourists' choices.

\footnotetext{
${ }^{1}$ World Trade Organization, Centre William Rappard, 154 rue de Lausanne, 1211 Geneva, 21, Switzerland. Correspondence to Matthias Helble.
} 
Khodyakov et al. (2017) revealed that Healthcare is a dynamic sector, significant changes have taken place and competition is increasing. Therefore, many managers are using patient opinions in quality improvement plans and projects to be a proactive HSOs.

Zolfagharian et al. (2018) investigated the factors underlying patients' opting for medical tourism instead of having a health care service in their home country. They found that the strong customer service, lower expenditure and high standards are the most significant reasons. Others studies have analysed more the variables affecting health tourism distention choice across various countries (Kumar and Hussian, 2016; Rezaee and Mohammadzadeh, 2016).

Alsarayreh et al. (2017), therefore, recommended to use modern technological ways in marketing Jordanian HSOs in a foreign country and to reassess the price with other competitive counties and to use more clear information to promote Jordan as a convenient medical tourism destination.

\section{Research Aim and Objectives}

Aim of this study is to investigate the role of digital marketing strategies in enhancing international patients' satisfaction in Jordanian health service industry. More specifically, the objectives of the study are to:

$>$ measure the effect of search engine optimization on international patients' satisfaction in Jordanian health service industry.

$>$ measure the effect of social media networks on international patients' satisfaction in Jordanian health service industry.

$>$ measure the effect of e-mail marketing on international patients' satisfaction in Jordanian health service industry.

$>$ provide practical implications and recommendations for enhancing patients' satisfaction using digital marketing in Jordanian health service industry.

\section{Digital marketing strategies}

Digital marketing means may include online marketing, Internet marketing, and web marketing (Todor, 2016). More specifically, Radu et al. (2015) emphasized the importance of employing social media by HSOs to promote their healthcare services and communicate the benefits.

The growing and pervasive trend of social media and digital marketing is apparent, therefore as Crittenden and Crittenden (2015) stated that social media methods' adoption is an essential form of marketing creativity. Therefore, digital marketing stands for consumer-marketer engagement that has been altered by digital marketing (Hansen et al., 2011; Crittenden and Crittenden, 2015). Radu et al. (2017) observed that digital marketing provides an opportunity to market a service to virtual customers, breaking the barrier of distance so the information being offered at any time and place, and targeting facility that has led to its being used by marketing managers in medical institutions as means of advertisement in marketing strategies. Moreover, patients may be reached via digital marketing with lower expenditure compared to direct marketing which entails higher expenditure.

One positive move by HSOs is to create a user-friendly website (Radu et al., 2017). Both workers and patients could derive knowledge from the site. Accordingly, contrast of costs, review of images, access to consumer feedback, services offered and medical institution information may all be accessed by potential patients on such a site, while keyword searches can bring up data very simply (Abubakar, 2016; Seow et al., 2017).

Patients' decision making regarding where to seek treatment is significantly affected by the information is made available to them online which enables them to plan the process more effectively (Jalilvand and Samiei, 2012; Johnston, 2012). Furthermore, Yazdanpanah et al. (2018) investigated the relation between digital marketing and medical tourism from medical tourism policymakers' perspective. They found that there is a strong relation between digital marketing and medical tourism destination selection from the viewpoint of policymakers. 
A digital marketing model comprising of five aspects: learn; retain; engage; attract, as well as relate, was developed by Kierzkowski et al. (1996). Based on Kierzkowski's work, Kim and Ko (2012) explored how consumer equality in relation to luxury fashion brands is strengthened through social media marketing. The result was a social media marketing model that consists of Word-of-mouth (WOM), customisation, trendiness, interaction and entertainment.

\section{Patients' satisfaction}

Many definitions and perceptions were tended for patients' satisfaction. Wagner and Bear (2009) defined it as the degree to which nursing care meets patients' expectations. Mohan et al. (2011) defined patients' satisfaction as patients' feelings, and emotions of healthcare service. Jain et al. (2017) defined it as the subjective perception of service quality derived from matching the expectations regarding the service with the actual experience and outcomes.

Quantitative, qualitative or mixed method research may be adopted for patients' satisfaction measurement, as Shirley (2016) explained. Patients' satisfaction may be measured more precisely through a quantitative rather than qualitative method, with satisfaction typically determined via a standardised questionnaire. Given that HSOs' activities are significantly influenced by the patients' satisfaction outcomes, identifying effective instruments that have dependability and validity is necessary for measuring such satisfaction with special healthcare circumstances (Yellen et al., 2002; Kilbourne et al., 2004; Al-Weshah, 2019b).

An appraisal of the patients' satisfaction conceptual framework was undertaken by Batbaatar et al. (2015), who sought to increase its influence on further operational processes. The researchers established that the extent to which the expectations of patients are met by healthcare facilities shapes patients' satisfaction models, with marketing theories usually underpinning these models (shaikh A 2015).

According to Rahmqvist (2011), based on Patients Satisfaction Index Score (PSI) several cautions related to the data resulting from patients' satisfaction surveys, as it is deeply influenced by patient demographics such as age, anxiety, income, and education (P. 388). So these variables must be adjusted while measuring patients' satisfaction.

Banaser et al. (2017) in their study aimed to examine the impact of interpersonal aspects, and sociocultural communication on patients' satisfaction in an oncology Cancer Centre in Saudi Arabia, sequential, explanatory, and mixed methods design were used in their study. The result showed patients' satisfaction levels are influenced by the interpersonal care aspects. Healthcare providerpatient relationships are considered as a core to patients' experiences. From the other hand, the sociocultural factors such as language barriers and dissimilarities have a negative impact on patients' satisfaction level. Accordingly, they recommended to improve the staff interpersonal skills and to consider the social and cultural differences.

Regarding the Patients Satisfaction Index Score (PSI), given that patient demographic characteristics including educational attainment, salary, anxiety and age can markedly affect responses, patients' satisfaction survey data should be treated cautiously to some extent. Ultimately, while determining patients' satisfaction, these factors need to be adjusted.

\section{Digital marketing strategies and Patients' satisfaction}

Engaging and communicating with target populations in a manner that is profitable, is the principal aim of communication and web-based tools being adopted for online marketing (Vella and Kester, 2008). Associate marketing software, web-based advertising, social media, email marketing and search engine marketing are just some of the types of web-orientated promotional process that define online marketing (Eley and Tilley, 2009). Smartphones, extranet and internet services may all comprise webbased marketing features of e-marketing, thus giving it a broader scope, whereas email and world wide web (www) services are the narrower focus of internet marketing (Dehkordi et al., 2012). Kompouros 
et al. (2015) recommended that social media marketing should be incorporated into the activities of all HSOs, so that patients' needs may be discovered and fulfilled.

Castro et al. (2017) in their study aim to provide a theoretical and practical contribution of digital marketing tools to promote tourist destinations. Official web page information, as well as semistructured focused interviews, provided the two data types for the case study method. They found that a highly beneficial technique was provided in the form of digital marketing methods for promoting tourist centres and medical destinations. Moreover, digital marketing customisation was found to be significant (Shahzad et al 2015).

Attracting new patients and offering them high-quality healthcare services in relation to digital marketing techniques were investigated by Radu et al. (2017). They took a sample of 126 patients in a Bucharest dental facility. The main results highlighted on the importance of promoting healthcare services using digital methods in order to expand a business and attract new patients and offering them high-quality healthcare services.

Overall, there are numerous e-marketing techniques are available, for example e-mail marketing, social media marketing, banner advertising, website marketing, search engine optimization (SEO), and mobile marketing (Dehkordi et al., 2012; Kaur et al., 2015; Al-Weshah, 2018). For this study, the SEO, social media networks, and e-mail marketing were adapted as main techniques to understand the digital marketing practices in HSOs.

\subsection{SEO}

SEO is a digital marketing method that is able to entice a greater volume of web page traffic. As Scott (2010) explained, a website's content may incorporate relevant keywords, which creates greater traffic volume because when a user searches for the same particular keywords in a search engine helps web pages to get as high ranking as possible on the landing pages and search engine (Opreana and Vinerean, 2015). HSOs employ SEO to facilitate the searching process for potential and existing customers so they can find relevant information and discover valuable content online (Pangirahi, 2016).

\subsection{Social media networks}

A pervasive contemporary marketing approach focuses on social media, which comprises of various techniques and technologies facilitating interaction between individuals (Scott, 2010). Furthermore, internet-based interaction between individuals occurs through various platforms that are defined as social media. The formulation and dissemination of user-produced content is promoted through the online applications comprising social media, which itself is underpinned by web 2.0's technical and ideological basis (Kaplan and Haenlein, 2010).

Social media has become a place for businesses to interact with consumers and create relationships with them (Brogan, 2010). As a result, HSOs need to produce different types of content in order to stay engaged and increase the engagement with the audience or patients as well as among patients themselves. Images, videos, podcasts and weblogs are just some of the types of social media (Pangirahi, 2016).

Leeflang et al. (2014) related how consumers who are less influenced by advertising, yet who may be more influenced by existing consumers through the information may be reached through social media networks. Information about the goods and services purchased by consumers, as well as customers' interpersonal engagement shape the consumer opinion that can be massively expanded in terms of accessibility through social media (Al-Weshah, 2018).

Social media output is used in customer decision-making such as shopping behavior, and postpurchase behaviour (Mayzlin and Yoganarasinhan 2012; Onishi and Manchanda, 2012). Social media marketing is a marketing technique that uses social platforms as communication tools with customers. 
Therefore, this two-way or bilateral interaction is the principal aim of social media marketing as it intensifies the effect on the company's content and consist of networks that help to distribute and assimilate information throughout the web (Opreana and Vinerean, 2015). In their study about health products, Alali et al (2019) investigated how to use social media to decrease energy drink consumption in Jordanian young adults and adolescents.

\subsection{E-mail marketing}

In terms of email marketing, it is considered as a fundamental and crucial technique for any business on any scale. Greater traffic may be attracted through the ability to communicate with target consumers through a higher volume of messages while benefitting from the reduced expenditure of email communication, indicating the practical benefits of email over standard mail. Furthermore, special deals may be conveyed to target consumers via repeat emails, as a means of maintaining consumers and strengthening their loyalty. Consequently, consumers' satisfaction may be enhanced through this marketing approach. As Chaffey (2003) explained, various choices can be offered to consumers to inform their decision making when communication is engaged in via email.

Scott (2010) defined how prospective and current consumers may be reached to advertise a firm's goods via email marketing. Updating consumer data, informing and prompting consumers, delivering information relating to the firm, strengthening a brand and showcasing new product, are all processes that may be engaged in through offering consumers relevant information through their emails (Li et al., 2017).

Thus, email marketing considered as one of the most effective digital marketing methods because it transfers data mining into personalized message to ensure customer satisfaction and increase loyalty (Sterne and Priore, 2010; Al-Weshah, 2019a)

\section{The study conceptual framework and hypotheses development}

Based on critical review of literature in digital marketing area, the conceptual framework of the study is developed to measure the effect of digital marketing on patients' satisfaction. The figure (1) is shown below.

Figure 1: The study conceptual framework

Independent Variable

Dependent Variable

Digital marketing strategies

- SEO

- Social media networks

- $\quad$ E-mail marketing

Source: The study model is adapted from Al-Weshah, 2018

Based on the study framework, the main hypothesis can be formulated. Accordingly, three subhypotheses can be extracted based on digital marketing strategies as follows.

The Main Hypothesis

HO: There is no significant effect of digital marketing strategies on international patients' satisfaction in Jordanian healthcare services.

The first sub-hypothesis:

H01: There is no significant effect of search engine optimization on international patients' satisfaction in Jordanian healthcare services.

The second sub-hypothesis: 
H02: There is no significant effect of social media networks on international patients' satisfaction in Jordanian healthcare services.

The third sub-hypothesis:

H03: There is no significant effect of e-mail marketing on international patients' satisfaction in Jordanian healthcare services.

\section{Methodology}

The study approach was a quantitative study and the data was gathered using structured selfadministrated questionnaire. 400 questionnaires were distributed to international patients in Jordan. Using convenient sample, the questionnaire was distributed for patients that were willing and ready to respond immediately. Five-Likert scale are considered as a measurement scale of the questionnaire for all items, and that scale ranges from 'very low' to 'very high'. Only 310 questionnaires are returned with response rate $78 \%$. Personal characteristics of respondents are shown in table 1.

Table1. Sample characteristics

\begin{tabular}{|l|c|c|}
\hline Personal characteristics & \multicolumn{2}{|c|}{ Prequency } \\
\hline Gender & 190 & 61.2 \\
\hline Male & 130 & 38.8 \\
\hline Female & \multicolumn{3}{|c|}{} \\
\hline Nationalities & 45 & 14.5 \\
\hline Iraqi & 62 & 20.0 \\
\hline Libyans & 51 & 16.5 \\
\hline Syrians & 32 & 10.3 \\
\hline Kuwaitis & 24 & 07.7 \\
\hline Sudan & 54 & 17.4 \\
\hline Palestinians & 42 & 13.6 \\
\hline Others & 125 & 40.3 \\
\hline Types of patients & 185 & 59.7 \\
\hline Inpatients & 182 & 58.7 \\
\hline Outpatients & 83 & 26.8 \\
\hline Financial coverage of treatment & 45 & 14.5 \\
\hline Personal & \multicolumn{2}{|l|}{} \\
\hline Insured & \multicolumn{2}{|l|}{} \\
\hline Sponsored &
\end{tabular}

According to table 1 , it is seen that the majority of responds are male. Major nationalities of respondents are Libyans, Palestinians, and Syrians respectively. Most of the respondents found to be outpatients who receive the healthcare service without staying overnight. Also, most of the respondents stated that they pay personally for their treatment cost. For instrument validity purposes, the questionnaire is pretested by seven academics and four experts in patient services and their comments are taken into account in the latest copy of the questionnaire.

Cronbach's Alpha method was calculated to measure the items reliability for the study variables, and the result showed high internal consistency to survey's questions (0.88) as shown in the table 2 .

Table 2: Reliability test

\begin{tabular}{|c|c|c|}
\hline Variables & Cronbach's Alpha & N of Items \\
\hline Search engine optimization & 0.851 & 8 \\
\hline Social media & 0.842 & 8 \\
\hline e-mail marketing & 0.861 & 6 \\
\hline Patients' satisfaction & 0.872 & 30 \\
\hline Overall & 0.880 & 8 \\
\hline
\end{tabular}




\section{Hypotheses testing and discussion}

In order to test the study hypotheses, simple and multiple linear regression are estimated.

\subsection{The effect of digital marketing on international patients' satisfaction.}

In order to measure the effect of digital marketing strategies on international patients' satisfaction, the main hypothesis stated that "there is no a significant effect of digital marketing strategies on international patients' satisfaction in Jordanian healthcare services." is tested using multiple regression model. The findings are shown in table 3.

Table 3: Multiple Regression results of digital marketing strategies

\begin{tabular}{|c|c|c|c|}
\hline Variables & Beta & $\mathbf{T}$ & Sig \\
\hline Search engine optimization & 0.172 & 2.513 & 0.031 \\
\hline Social media networks & 0.124 & 2.246 & 0.000 \\
\hline e-mail marketing & 0.142 & 2.152 & 0.001 \\
\hline $\mathbf{R}^{\mathbf{2}}$ & \multicolumn{3}{|c|}{0.472} \\
\hline $\mathbf{F}$ & \multicolumn{3}{|c|}{52.268} \\
\hline Sig & \multicolumn{3}{|c}{0.000} \\
\hline
\end{tabular}

According to the table (3), the results of multiple regression show that there is a significant effect of digital marketing strategies on international patients' satisfaction in Jordanian healthcare services, since $(F=52.268, P<0.05)$, therefore, the null hypothesis is rejected and the alternative hypothesis is accepted. The results show that $(R 2=0.472)$ which indicate that digital marketing strategies explains $47.2 \%$ of the variance in international patients' satisfaction in Jordanian healthcare services. This result is supported with some previous studies such as by Al-Weshah (2018) and Radu et al. (2017).

\subsection{The effect of search engine optimization on international patients' satisfaction}

In order to measure the effect of "search engine optimization" as a digital marketing strategy on international patients' satisfaction, the first sub-hypothesis stated that "there is no a significant effect of search engine optimization on international patients' satisfaction in Jordanian HSOs is tested using simple regression model. The findings are shown in table 4.

Table 4: Simple Regression results for "Search engine optimization"

\begin{tabular}{|l|c|c|c|c|}
\hline \multirow{2}{*}{ Search engine optimization } & $\mathbf{R}$ & $\mathbf{R}^{\mathbf{2}}$ & $\mathbf{T}$ & Sig \\
\cline { 2 - 5 } & 0.522 & 0.272 & 10.721 & 0.210 \\
\hline
\end{tabular}

The table (4) indicates that there is a significant effect of search engine optimization on international patients' satisfaction, since ( $\mathrm{t}=10.721, \mathrm{P}<0.05)$, therefore, the null hypothesis is rejected and the alternative hypothesis is accepted. The results show that $(R 2=0.272)$ this means that search engine optimization explains $27.2 \%$ of the variance in international patients' satisfaction in Jordanian health services. This result is supported by Al-Weshah (2018).

\subsection{The effect of social media networks on international patients' satisfaction}

In order to measure the effect of "social media networks" as a digital marketing strategy on international patients' satisfaction, the second sub-hypothesis stated that "there is no a significant effect of social media networks on international patients' satisfaction in Jordanian HSOs is tested using simple regression model. The findings are shown in table 5.

Table 5: Simple Regression results for "Social media networks"

\begin{tabular}{|l|c|c|c|c|}
\hline \multirow{2}{*}{ social media networks } & $\mathbf{R}$ & $\mathbf{R}^{\mathbf{2}}$ & $\mathbf{T}$ & Sig \\
\cline { 2 - 5 } & 0.625 & 0.390 & 10.811 & 0.00 \\
\hline
\end{tabular}


The table (5) indicates that there is a significant effect of social media networks on international patients' satisfaction, since ( $\mathrm{t}=10.811, \mathrm{P}<0.05)$, therefore, the null hypothesis is rejected and the alternative hypothesis is accepted. The results show that $(R 2=0.272)$ this means that social media networks explains $39 \%$ of the variance in international patients' satisfaction in Jordanian health services. This result is supported by Al-Weshah (2018) and Radu et al. (2017)

\subsection{The effect of e-mail marketing on international patients' satisfaction}

To measure the effect of "e-mail marketing" as a digital marketing strategy on international patients' satisfaction, the third sub-hypothesis stated that "there is no a significant effect of e-mail marketing on international patients' satisfaction in Jordanian HSOs is tested using regression model. The findings of analysis are shown in table 6.

Table 6: Simple Regression results for "e-mail marketing"

\begin{tabular}{|l|c|c|c|c|}
\hline \multirow{2}{*}{ e-mail marketing } & $\mathbf{R}$ & $\mathbf{R}^{\mathbf{2}}$ & $\mathbf{T}$ & Sig \\
\cline { 2 - 5 } & 0.611 & 0.373 & 10.122 & 0.00 \\
\hline
\end{tabular}

The table (6) shows that there is a significant effect of e-mail marketing on international patients' satisfaction in Jordanian health services, since $(t=10.122, P<0.05)$, thus, the null hypothesis here is rejected and the alternate hypothesis is accepted. The results indicate that $(R 2=0.373)$ this means that e-mail marketing explains $37.3 \%$ of the variance in international patients' satisfaction in Jordanian health services. This result is supported by Al-Weshah (2018) and Li et al., (2017)

\section{Findings of the study and practical implications}

This study focuses on digital marketing strategies and international patients' satisfaction in Jordanian health service industry. Specifically, this study measures digital marketing strategies based on three strategies, namely, search engine optimization, social media networks, and e-mail marketing. In the light of critical review of the literature in digital marketing field, the study develops a theoretical framework that relates digital marketing strategies and international patients' satisfaction in Jordanian health service industry.

Based on linear regression analysis and hypotheses testing approach, the findings states that null hypotheses were rejected and the alternate hypotheses were accepted. Thus, the results clearly show that there is a significant effect of digital marketing strategies on international patients' satisfaction in Jordanian health service industry. Moreover, each digital marketing strategies (search engine optimization, social media networks, and e-mail marketing) have a significant effect on international patients' satisfaction in Jordanian health service industry. Specifically, the study has ranked the digital marketing strategies as social media networks, e-mail marketing, and search engine optimization respectively and from the most to the least effective one.

The theoretical model in present study is verified. Accordingly, digital marketing strategies are adopted in Jordanian health service industry. Marketing executives' HSOs can employs the proposed model to enhance international patients' satisfaction.

The study also provides insights about digital marketing strategies by developing comprehensive framework of digital marketing in HSOs. The study confirms that marketing practices in HSOs should be transformed from traditional marketing to digital marketing. Moreover, HSOs have to take the advantages of digital marketing strategies to enhance patients' satisfaction.

For marketing staff, digital marketing can reduce spending on offline marketing activities, such as direct mail, personal visits, billboards and TV ads. HSOs need to use digital channels to implement social media marketing, search engine marketing, and email marketing strategies. Digital transformation of marketing offers HSOs an opportunity to engage with international patients, and meet their expectations of a seamless patient experience regardless of geographical location. 


\section{Limitations and further research}

Strategies of digital marketing such as mobile marketing can be taken into account in future research. Theoretical framework of the present study can be extended to different industries such as financial and manufacturing industries. Methodologically, qualitative approach may be adopted in future research.

\section{Acknowledgements}

This paper was submitted to the conference of "ICSIEM"20, and funded by Al-Balqa Applied University- Jordan.

\section{References}

1. Abubakar, M. A. (2016). Does eWOM influence destination trust and travel intention: a medical tourism perspective. Economic research-Ekonomskaistraživanja, 29(1), 598-611.

2. Al-Abri, R., \& Al-Balushi, A. (2014). Patients' satisfaction survey as a tool towards quality improvement. Oman medical journal, 29(1), 3

3. Alali,H. Wishah, R. \& Al-Weshah, G. (2019). The Demarketing of Energy Drinks Using Facebook Media: A Healthcare Perspective. International Journal on Advanced Science, Engineering and Information Technology, 9 (3), 835-840.

4. Al-Azzam, A. F. M. (2016). A study of the impact of marketing mix for attracting medical tourism in Jordan. International Journal of Marketing Studies, 8(1), 139-149.

5. Al-Hinai, S. S., Al-Busaidi, A. S., \& Al-Busaidi, I. H. (2011). Medical tourism abroad: A new challenge to Oman's health system-Al Dakhilya region experience. Sultan Qaboos University Medical Journal, 11(4), 477

6. Ali, Z., Ejaz, S., Almeen, A., Saeed, M., Tahir, F., \&Kashif, M. (2015). Understanding E-Marketing as a Firm'sPromotional tool: It's Impact on Consumer Perception. International Journal of Academic Research in Business and Social Sciences, 5(4), 166-180.

7. Alsarayreh, M. N., Al Nawaiseh, K. H. A., Mahasneh, M. S. M., \&Rumman, M. A. R. A. (2017). Medical Tourism and Its Role in Marketing Jordan Abroad. International Review of Management and Marketing, 7(4), 180-185.

8. Al-Weshah, G. (2017), "Marketing intelligence and customer relationships: empirical evidence from Jordanian banks", Journal of Marketing Analytics, Vol. 5 No. 3/4, pp. 141-152.

9. Al-Weshah, G. (2018). E-marketing practices from Jordanian tourism agencies perspectives: a qualitative evidence. International Journal of Online Marketing (IJOM), 8(1), 21-36.

10.Al-Weshah, G. (2019a), "Towards Internal Marketing Practices in Enhancing Job Engagement: Practical Evidence from Jordanian Hospitals", International Journal of Pharmaceutical and Healthcare Marketing, Vol.13 No.1, pp.40-46.

11.Al-Weshah, G. (2019b), "The current status of customer relationship management: experience of small businesses in Jordanian food industry", International Journal of Electronic Customer Relationship Management, Vol. 12 No.1, pp. 1-20.

12.Banaser, M., Stoddart, K., \& Cunningham, N. (2017). A Qualitative Study of Patient satisfaction in Oncology Wards Setting in Saudi Arabia. Research and Reviews: Journal of Nursing and Health Sciences, 3(3), 85-97.

13.Batbaatar, E., Dorjdagva, J., Luvsannyam, A., \&Amenta, P. (2015). Conceptualisation of patient satisfaction: a systematic narrative literature review. Perspectives in Public Health, 135(5), 243250.

14.Becerril-Arreola, R., Zhou, C., Srinivasan, R., \& Seldin, D. (2017). Service satisfaction-market share relationships in partnered hybrid offerings. Journal of Marketing, 81(5), 86-103. 
15.Burkle, C. M., Njathi, C. W., Stoike, D. E., Johnson, C. S., Klompas, A. M., Niesen, A. D., \& Jacob, A. K. (2017). Patient retention and satisfaction with information exchange concerning peripheral nerve block risks. Canadian Journal of Anesthesia/Journal canadiend'anesthésie, 64(10), 1075-1076.

16.Castro, S., Silva, S. C., \& Duarte, P. (2017). Do Digital Marketing really boost city tourism? Evidences from Porto's Experience. European Journal of Applied Business and Management, 3(3).

17.Chaffey, D. (2003). Total E-mail Marketing. Great Britain: Marketing Insights Ltd.

18.Chiou, J., \&Droge, C. (2006). Service Quality, Trust, Specific Asset Investment, and Expertise: Direct and Indirect Effects in a Satisfaction-Loyalty Framework.Journal of the Academy of Marketing Science, 34 (4), 613-27.

19.Crittenden, V. L., \& Crittenden, W. F. (2015). Digital and Social Media Marketing in Business Education: Implications for Student Engagement. Journal of Marketing Education, 37(3), 131-132

20.Dehkordi, G., Rezvani, S., Rahman, M., Fouladivanda, F., \&Jouya, S. (2012). A conceptual study on E-marketingand its operation on firm's promotion and understanding customer's response. International Journal of Business and Management, 7(19), 114-124.

21.Dhodi, K., Uniyal, M., \& Sharma, M. S. (2014). Trends and Scope of Medical Tourism: Case Study of Delhi NCR, India. International Research Journal of Business and Management-IRJBM, 2014(2), 1325.

22.Eley and Tilley. (2009). Online marketing inside out. Australia: Site Point Pty Ltd.

23.Graham, B. (2016). Defining and measuring patient satisfaction. The Journal of hand surgery, 41(9), 929-931.

24.Hansen, D., Shneiderman, B., \& Smith, M. A. (2011). Analyzing social media networks with NodeXL: Insightsfrom a connected world. Boston: Elsevier.

25. Hawkins, J. B., Brownstein, J. S., Tuli, G., Runels, T., Broecker, K., Nsoesie, E. O., \& Greaves, F. (2016). Measuring patient-perceived quality of care in US hospitals using Twitter. BMJ QualSaf, 25(6), 404413.

26.Jalilvand, R. M. \&Samiei, N. (2012). The impact of electronic word of mouth on a tourism destination choice: Testing the theory of planned behavior (TPB). Internet Research, 22(5), 591-612.

27.Jain, D., Nguyen, L. C. L., Bendich, I., Nguyen, L. L., Lewis, C. G., Huddleston, J. I., \&Bozic, K. J. (2017). Higher patient expectations predict higher patient-reported outcomes, but not satisfaction, in total knee arthroplasty patients: a prospective multicenter study. The Journal of arthroplasty, 32(9), 166170.

28.Johnston, R., Crooks, V. A., \& Snyder, J. (2012). "I didn't even know what I was looking for": A qualitative study of the decision-making processes of Canadian medical tourists. Globalization and health, 8(1), 23.

29.Kaplan, A. M., \&Haenlein, M. (2010). Users of the world, unite! The challenges and opportunities of SocialMedia. Business Horizons, 53(1), 59-68.

30.Kaur, G. (2017). The importance of digital marketing in the tourism industry. International Journal of Research-Granthaalayah, 5(6), 72.

31.Kaur, P., Pathak, A., \& Kaur, K. (2015). E-Marketing- a global perspective. Int. Journal of Engineering Research and Applications, 5(2), 116-124.

32.Khodyakov, D., Stockdale, S. E., Smith, N., Booth, M., Altman, L., \& Rubenstein, L. V. (2017). Patient engagement in the process of planning and designing outpatient care improvements at the Veterans Administration Health-care System: findings from an online expert panel. Health Expectations, 20(1), 130-145.

33.Kierzkowski, A., McQuade, S., Waitman, R., \&Zeisser M. (1996). Marketing to the digital consume. Mckinsey Quarterly,3(1996), 4-21

34.Kilbourne, A. M., McCarthy, J. F., Post, E. P., Welsh, D., Pincus, H. A., Bauer, M. S., et al. (2006). Access to and satisfaction with care comparing patients with and without serious mental illness. International Journal of Psychiatry in Medicine,36(4), 383-399.

35.Kim, A. J., \&Ko, E. (2012). Do social media marketing activities enhance customer equity? An empirical study of luxury fashion brand. Journal of Business research, 65(10), 1480-1486. 
36.Kotler, P., Bowen, J. T., Makens, J., \&Baloglu, S. (2017). Marketing for hospitality and tourism, Pearson, UK.

37.Koumpouros, Y., Toulias, T. L., \&Koumpouros, N. (2015). The importance of patient engagement and the use of social media marketing in healthcare. Technology and Health Care, 23(4), 495-507.

38. Kumar, J., \&Hussian, K. (2016). Factors affecting medical tourism destination selection: A Malaysian perspective. Journal of Global Business Insights, 1(1), 1-10.

39.Ledford, J. L. (2008). Search Engine Optimization Bible. Indiana: Wiley Publishing.

40.Leeflang, P. S. H., Verhoef, P. C., Dahlström, P., \&Freundt, T. (2014). Challenges and solutions for marketingin a digital era. European Management Journal, 32(1), 1-12.

41.Li, S. C., Robinson, P., \&Oriade, A. (2017). Destination marketing: The use of technology since the millennium. Journal of destination marketing \& management, 6(2), 95-102.

42.Mayzlin, D., \&Yoganarasinhan, H. (2012). Link to success: How blogs build an audience bypromoting rivals. Management Science, 58 (9), 1651-1668.

43.Merisavo, M., \&Raulas, M. (2004). The impact of e-mail marketing on brand loyalty. Journal of Product and Brand Management, 13(7), 498-505.

44.Pangirahi, A. (2016). E-Marketing - leading edge for booming business worldwide. Journal of Management Research and Analysis, 3(3), 131-135.

45.Onishi, H., \&Puneet M. (2012). Marketing activity, blogging andsales.International Journal of Research in Marketing, 29 (3), 221-234.

46.Opreana, A., \&Vinerean, S. (2015). A new development in online marketing: introducingdigital inbound marketing. Expert Journal of Marketing, 3(1), 29-34.

47.Radu, G., Solomon, M., Gheorghe, C. M., Hostiuc, M., Bulescu, I. A., \&Purcarea, V. L. (2017). The adaptation of health care marketing to the digital era. Journal of medicine and life, 10(1), 44-46.

48. Rahmqvist, M. (2001). Patient satisfaction in relation to age, health status and other background factors: a model for comparisons of care units. Int J Qual Health Care, 13, 385-390.

49. Rezaee, R., \&Mohammadzadeh, M. (2016). Effective factors in expansion of medical tourism in Iran. Medical journal of the Islamic Republic of Iran, 30, 409.

50.Shaikh, A. (2015). The impact of SOA on a system design for a telemedicine healthcare system. Network Modeling Analysis in Health Informatics and Bioinformatics, 4(1), 1-16.

51.Scott, D. M. (2010). The New Rules of Marketing and PR: How to Use Social Media, Blogs, News Releases, Online Video, \& Viral Marketing to Reach Buyers Directly. USA: John Wiley \& Sons.

52.Seow, A. N., Choong, Y. O., Moorthy, K., \& Chan, L. M. (2017). Intention to visit Malaysia for medical tourism using the antecedents of Theory of Planned Behaviour: A predictive model. International Journal of Tourism Research, 19(3), 383-393.

53.Shahzad, B., Abdullatif, A. M., Saleem, K., \& Jameel, W. (2017). Socio-Technical Challenges and Mitigation Guidelines in Developing Mobile Healthcare Applications. Journal of Medical Imaging and Health Informatics, 7(3), 704-712.

54.Shirley, E., Josephson, G., \& Sanders, J. (2016). Fundamentals of patient satisfaction measurement. Physician leadership journal, 3(1), 12.

55.Sterne, J., \&Priore, A. (2000). Email marketing: using email to reach your target audience and build customer relationships. John Wiley \& Sons, Inc.

56.Tartaglione, A. M., Cavacece, Y., Cassia, F., \& Russo, G. (2018). The excellence of patient-centered healthcare. The TQM Journal, 30(2), 153-167.

57.Todor, R. D. (2016). Blending traditional and digital marketing. Bulletin of the Transilvania University of Brasov. Economic Sciences. Series V, 9(1), 51.

58.Vella, L. \& Kester, J. (2008). Handbook on E-marketing for tourism destination. Madrid, Spain: World TourismOrganization and the European Travel commission.

59.Vogus, T. J., \& McClelland, L. E. (2016). When the customer is the patient: Lessons from healthcare research on patient satisfaction and service quality ratings. Human Resource Management Review, 26(1), 37-49. 
60.Voutilainen, A., Pitkäaho, T., Kvist, T., \&Vehviläinen-Julkunen, K. (2016). How to ask about patient satisfaction? The visual analogue scale is less vulnerable to confounding factors and ceiling effect than a symmetric Likert scale. Journal of advanced nursing, 72(4), 946-957.

61.Wagner, D., \& Bear, M. (2009). Patient satisfactionwith nursing care: A concept analysis withina nursing framework. Journal of Advanced Nursing, 65(3), 692-701

62.Weinberg, T. (2009). The new community rules: Marketing on the social web. O'Reilly Media.

63.Yazdanpanah, A., Parsaei, A., \&Jeihooni, A. K. (2018). The role of digital marketing in medical tourism industry in point of view of medical tourism policy makers of Shiraz in. Pharmaceutical Research, 3(1), 63-68.

64.Yellen, E., Davis, G. C., \& Ricard, R. (2002). The measurement of patient satisfaction. Journal of Nursing Care Quality, 16(4), 23-29.

65.Zolfagharian, M., Rajamma, R. K., Naderi, I., \&Torkzadeh, S. (2018). Determinants of medical tourism destination selection process. Journal of Hospitality Marketing \& Management, 27(7), 775794. 